\title{
Applications of Micro-Raman Spectros- copy in Cultural Heritage - Examples from the Laboratory for Conservation Research of the Collections Centre of the Swiss National Museums
}

\author{
Olivier Berger ${ }^{\mathrm{b}}$, Pascale Bonnard Yersin ${ }^{\mathrm{c}}$, Jean-Marc Bonnard Yersin ${ }^{\mathrm{c}}$, Chantal Hartmann ${ }^{\mathrm{d}}$, \\ Erwin Hildbrand ${ }^{\mathrm{a}}$, Vera Hubert ${ }^{\mathrm{a}}$, Katja Hunger ${ }^{\mathrm{a}}$, Marianne Ramstein ${ }^{\mathrm{d}}$, and Marie Wörle ${ }^{\star a}$
}

\begin{abstract}
The paper reports on three applications of micro-Raman spectroscopy which were carried out in the Laboratory for Conservation Research of the Collections Centre of the Swiss National Museums. The first application addresses archaeological questions about three early mediaeval fibulae which were decorated with gemstones. The determination of different corrosion products on pigeon cameras by micro-Raman spectroscopy is described in the second part of this article. The last case study discusses an example from the field of preventive conservation where changes on metal coupons from the so-called Oddy test were analysed.
\end{abstract}

Keywords: Corrosion product · Garnet · Micro-Raman spectroscopy · Pigeon cameras · Preventive conservation

\section{Introduction}

The Collections Centre of the Swiss National Museums in Affoltern am Albis opened its doors in 2007.[1] It is a state-of-the-art facility which combines newly designed conservation treatment and research laboratories, with a photographic studio and, above all, the museum's extensive storage facility with its modern registration and lending system. Housed are about 800000 objects that comprise the museum's entire

${ }^{\star}$ Correspondence: Dr. M. Wörle ${ }^{\mathrm{a}}$

Tel. : 41447621390

Fax: + 41447621361

E-mail: marie.woerle@sIm.admin.ch

aLaboratorium für Konservierungsforschung

Sammlungszentrum

Schweizerische Landesmuseen

Lindenmoostrasse 1

$\mathrm{CH}$-8910 Affoltern am Albis

${ }^{b}$ Art Metal Conservation $\mathrm{GmbH}$ Basle

Pilgerstr. 2

$\mathrm{CH}-4055$ Basel

'Musée suisse de l'appareil photographique

Grande-Place 99

$\mathrm{CH}-1800$ Vevey

${ }^{d}$ Archäologischer Dienst des Kantons Bern

Bereichsleitung Siedlungs- und Gräberfeldarchäologie

Brünnenstr. 66

Postfach 5233

$\mathrm{CH}-3001$ Bern collections since the foundation in 1898 These objects are contemporary witnesses of Switzerland's history, art and its multicultural society. The substantial variety of objects - from amber and gold beads of Neolithic Age to 'Lilith', the first computer designed at the ETH Zurich in 1978, or the Zurich bourgeois family portraits - comprises a wide range of materials such as wood, textiles, leather, metals, glass, gemstone, stone, ceramics, plastics and others.

The laboratory for conservation research is dedicated to provide the most suitable and advanced techniques to examine and characterise artwork, historical artefacts and related degradation phenomena. The scientists closely collaborate with the conservators of the Collections Centre, continuously developing and optimising preventive measures and conservation treatments. The laboratory is thus equipped with several non-destructive or minimal impact analytical techniques to satisfy the demands posed by the variety of materials, sizes and the conservation status of the objects. X-ray fluorescence spectrometry (XRF), Fourier transform infrared spectroscopy equipped with a diamond press cell and movable ATR objective (FTIR), flame and graphite furnace atomic absorption spectrometry (AAS), light microscopy (LM), and since 2005 a dispersive micro-Raman spectros- copy system with an external option for bulky objects.

This paper focuses on Raman spectroscopy and presents three typical cases in conservation research: one archaeological example dealing with three medieval fibulae; another example researching a conservation treatment; and a third case on testing material suitability for use in storage or presentation of artefacts.

\section{Experimental Section}

The Raman technique is only briefly outlined here. The method is based on the Raman effect which was discovered in 1928 by C. V. Raman who received the Nobel prize for his scientific work in 1930. ${ }^{[2]}$ Over the last 15 years Raman spectroscopy has become established as a remarkably effective method for the identification of a wide range of materials in art and archaeology. ${ }^{[3-5]}$

Due to its non-destructive nature combined with high specificity at a spatial resolution of down to 1 micron, the method has been successfully applied to the identification of pigments, dyes, binders in paintings and textiles, conservation materials and other chemicals used by the conservators, identification of gemstones and their inclu- 
sions, studies on ceramics, investigation of corrosion products of glass or metals to name a few. The sample is irradiated with monochromatic laser light, typically in the range from UV to NIR. Most of the light is scattered elastically (Rayleigh scattering) while a small part is scattered inelastically by molecule and lattice oscillation (Raman effect). The energy and frequency differences are specific to the composition of the material. The resulting spectrum is compared with reference spectra libraries. This laboratory applies a Labram Aramis Raman spectrometer (Horiba Jobin Yvon), equipped with a Peltier-cooled Open-Electrode CCD $(1024 \times 256$ pixel $)$, fully automated grating system $(600-1800 \mathrm{gr} / \mathrm{mm})$, edge filter and laser selection between a He/ $\mathrm{Ne}$ laser at $632.8 \mathrm{~nm}$ and a Nd:YAG laser at $532 \mathrm{~nm}$. The backscattered light is collected through $10 \times, 50 \times$ and $100 \times$ Olympus objective lenses. To enable analysis of bulky samples, a horizontal tube that may be combined with different objectives, adds to the standard motorised sample stage analyses of small or thin samples.

\section{Case Study 1: Application of Micro-Raman Spectroscopy to Archaeological Artefacts}

Three early medieval fibulae from the excavation of two women's tombs in Langenthal Unterhard (BE) were investigated by Raman spectroscopy. The tombs are dated to the 6th century AD. ${ }^{[6]}$ Fibulae are pieces of jewellery mostly made from metal. They were worn by men and more often by women to fix their clothes, such as cloaks. Their function can be described like that of a safety pin. Thus, they consist of a needle and a clip or a plate, often with artful decoration. Forms and style of the fibulae can be assigned to specific historical periods and different civilisation groups.

In the first tomb, a pair of fibulae was found in the pectoral region. Both are modelled in an S-shape representing animals with backward glances (Fig. 1). This type of fibulae is known as a 'Tierfibel', animal fibula. In the second tomb, a single fibula was found in the neck region. Again in an Sshape, it symbolises a twin bird's head (Fig. 2). This type is a so-called 'Vogelkopffibel' (bird fibula). ${ }^{6]}$ All three examples display a mechanically structured surface and dark red inlays. These are typical for the early medieval period. ${ }^{[7]}$ The two tombs are of particular interest because they document a change of fashion in the way fibulae were worn during the 6th century. At the beginning of the 6th century, women used to wear a pair of fibulae to close their garments while, a century later, only one was worn. Because of this, archaeologists were interested in characterisation of the materi-

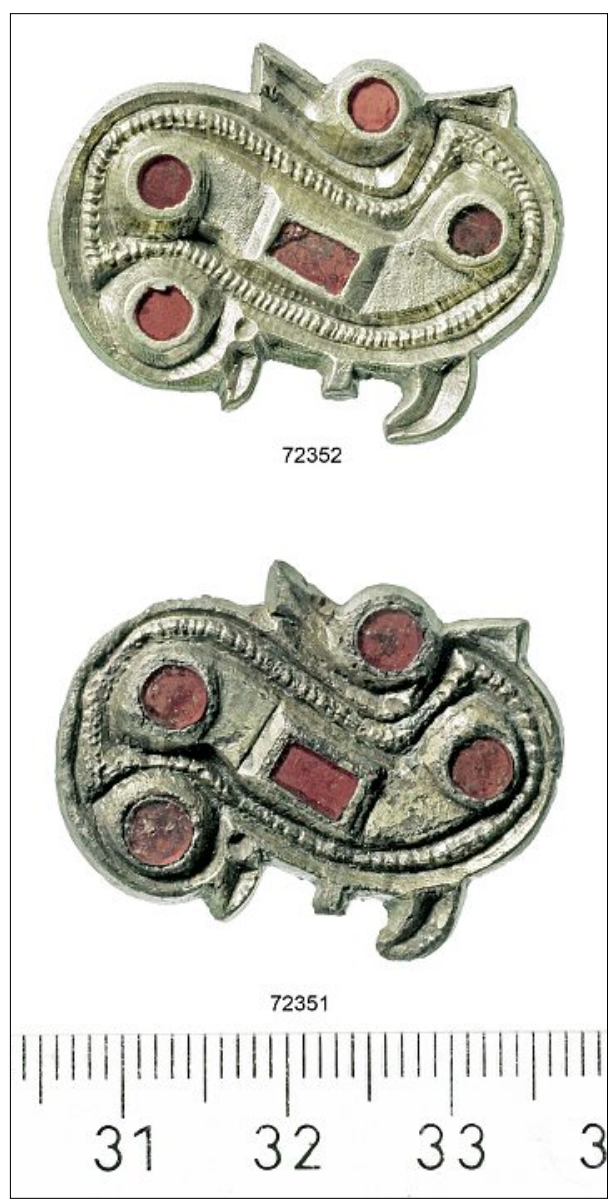

Fig. 1. Two animal fibulae of tomb 95 from Langenthal (BE), photo: Badri Redha, Archäologischer Dienst des Kantons Bern

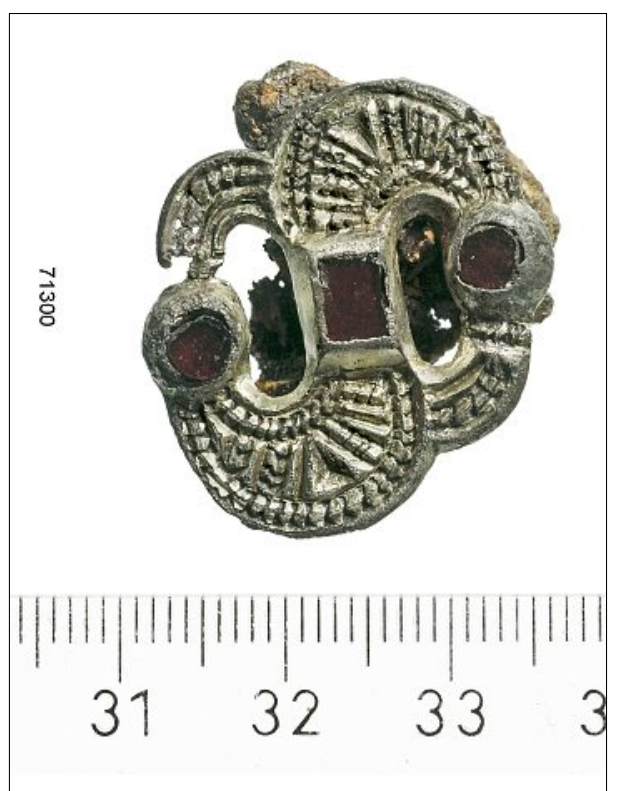

Fig. 2. The 'Vogelkopffibel' of tomb 34 from Langenthal (BE), photo: Badri Redha, Archäologischer Dienst des Kantons Bern

als in order to obtain a better archaeological classification of these three fibulae. Thus, both the composition of the metal alloys and the identification of the red inlays were of relevance.
The analysis of the composition of the metal alloys was carried out by non-destructive micro-XRF spectroscopy. While all were fire-gilded, the bird fibula contains pure silver, whereas the pair of animal fibulae consists of a silver and copper alloy. The red inlays of the three fibulae were analysed non-destructively by applying micro-XRF and micro-Raman spectroscopy. The XRF analyses of the inlays show very similar results. The main elements detected were iron (60-68 wt \%), aluminium (11-13 wt \%) and silicon (19-21 wt\%), with traces of copper, calcium and manganese (below $1 \mathrm{wt} \%$ ). This composition is typical for an iron-rich garnet mineral. ${ }^{[8]}$

Direct micro-Raman analyses of all inlays using the $532 \mathrm{~nm}$ excitation resulted in Raman bands at 344 and $917 \mathrm{~cm}^{-1}$, identifying the mineral almandine $\left(\mathrm{Fe}_{3} \mathrm{Al}_{2}\left(\mathrm{SiO}_{4}\right)_{3}\right) \cdot{ }^{[9]}$ Furthermore, the spectra display peaks at 1452 and $2036 \mathrm{~cm}^{-1}$ which are assigned to polyethylmethacrylate applied during a previous conservation treatment (Figs. 3 and 4). Between 5th and 7th century AD almandines were commonly used in jewellery. They were mainly imported from India. Economically viable garnet deposits in Europe are rare and most raw gemstones were traded from India. During the 7 th century, the form and size of gem garnets changed because of a break in the trade routes between Asia and Europe arising from the conflicts between Byzantium and Persia. This favoured the import of garnets from Bohemia.

\section{Case Study 2: Raman Spectroscopy Used in a Conservation Working Process}

In 1908, aerial photographs of a castle in Bavaria, Germany, were taken by a camera developed for carrier pigeons by Julius Neubronner. However, Neubronner's invention was not made public. More than twenty years later, Christian Adrian Michel, the head of a family business of watchmakers in Walde (AG), heard about this idea and picked it up, refined it and developed a first prototype intended for commercial production. Michel offered the pigeon cameras to the Swiss army in 1937. In the same year, first tests were carried out by aircraft at the airport in Dübendorf $(\mathrm{ZH})$. More tests with different cameras carried by pigeons resulted in eight films of good quality. After composing a manual for the use of the cameras, Michel offered his development to different companies for production. The break-out of the Second World War in 1939 stopped the request and pigeon cameras were never commercialised. Michel's children donated the cameras, manuals, and the films and documents to the Swiss Camera Museum in Vevey (VD). ${ }^{[10]}$ The museum kept three 


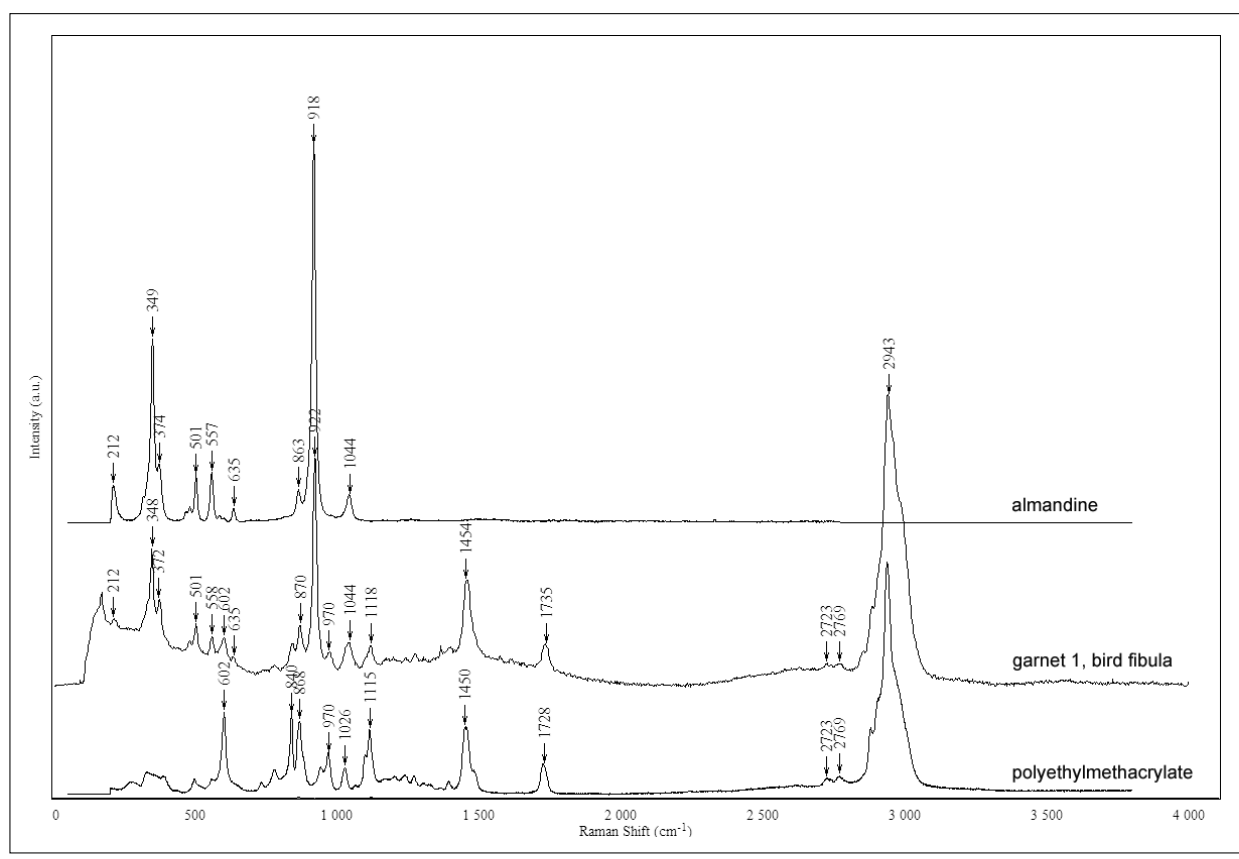

Fig. 3. Comparison of an almandine and polyethylmethacrylate sample with the spectrum of one of the garnets of the bird fibula

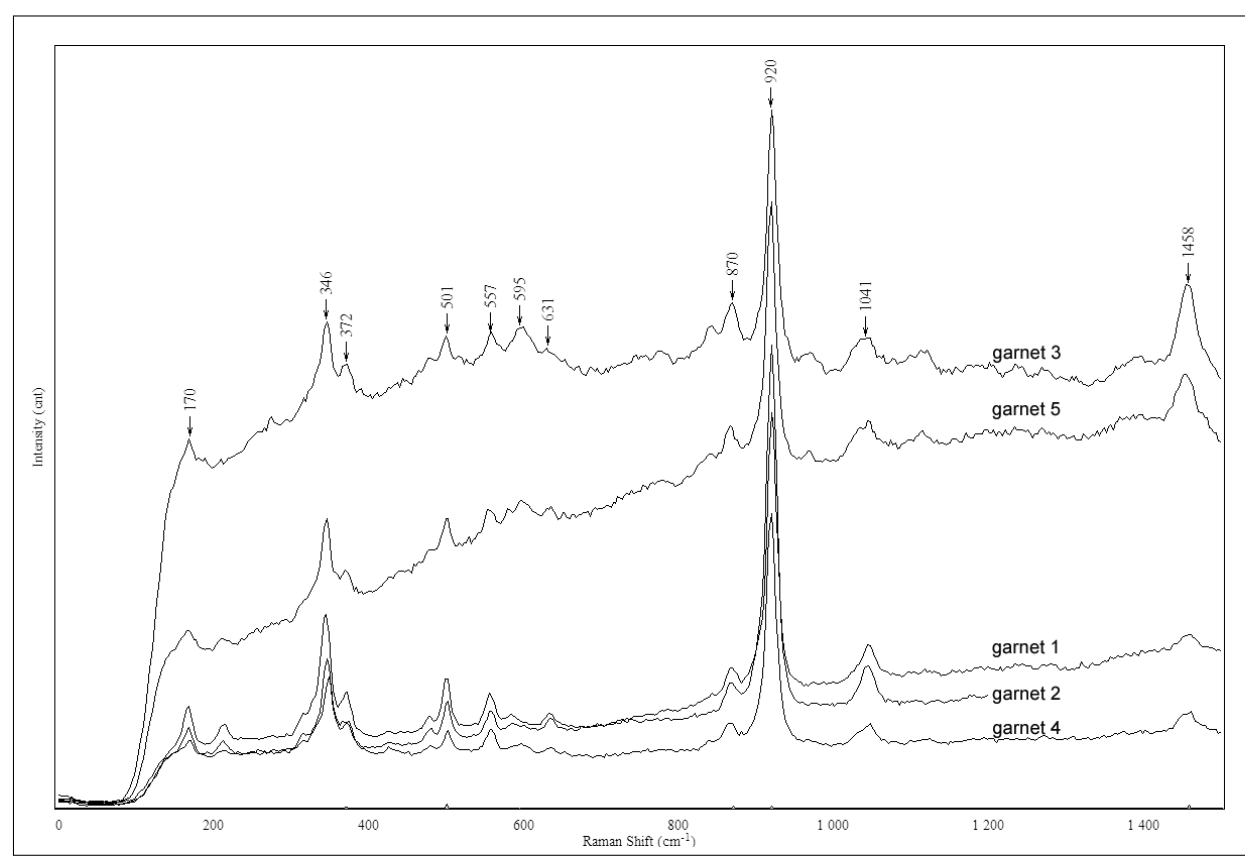

Fig. 4. Garnets $1-5$ of one of the animal fibulae
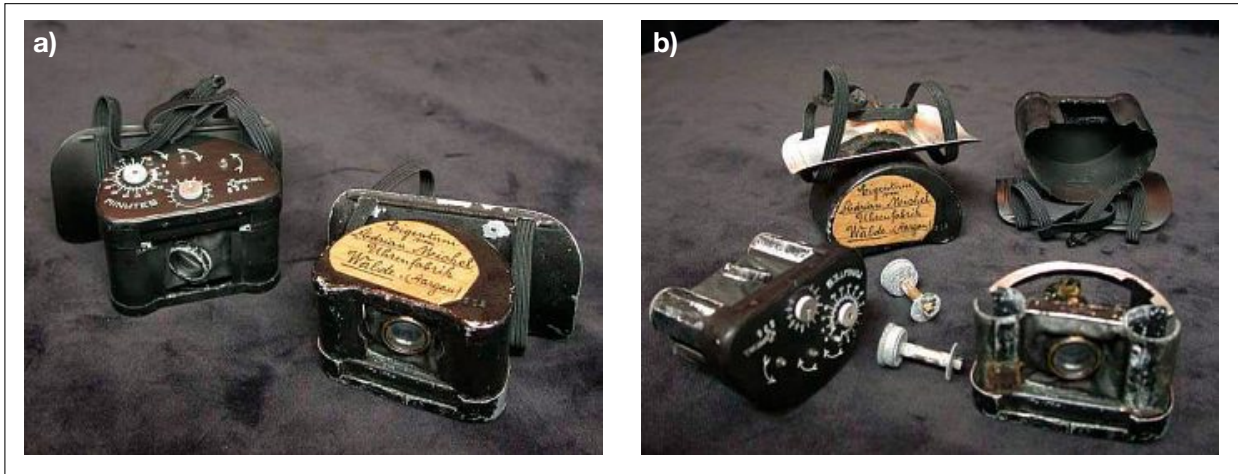

Fig. 5. Pigeon cameras cameras (one prototype) and films on the production and mechanics of the cameras. In 2006, the first series of these objects was sent to Art Metal Conservation $\mathrm{GmbH}$ in Basel for conservation. The research laboratory of the Collections Centre was approached to characterise the metal alloys and the thick white corrosion products covering most of the camera's components. The results of the analyses were of great importance for the conservation strategy.

The cameras are complex constructions with a small inner part containing the film reels with films and a reel cap. This part is painted in black. The inner part has an opening where the objective could be fixed and is sealed with a textile against light. It fits into a casing with black paint. This casing carried the automatic release. In Fig. 5a and b two models are shown. Fig. 6 illustrates the corroded objective and reel cap. The metal of the inner part could be identified by micro-XRF as two different aluminium alloys, whereas the film reels, the reel caps and the film rolls are made from the same magnesium alloy with small amounts of aluminium. The outer part of the objective is made from a similar magnesium alloy.

The thick layer of white corrosion products on the film reels, the film reel cap (Fig. 6 ) and on the objective were of particular interest regarding conservation. All of these highly corroded parts are made from the magnesium alloy with small amounts of aluminium. Small samples of these white corrosion products were taken from each part of the camera and analysed using Raman spectroscopy with $532 \mathrm{~nm}$ excitation. Two different corrosion products could be identified (Fig. 7); magnesium acetate $\left(\left(\mathrm{Mg}\left(\mathrm{CH}_{3} \mathrm{COO}\right)_{2} \cdot 4 \mathrm{H}_{2} \mathrm{O}\right)\right.$ and hydromagnesite $\left(\mathrm{Mg}_{5}\left(\mathrm{CO}_{3}\right)_{4}(\mathrm{OH})_{2} \cdot \mathrm{H}_{2} \mathrm{O}\right)$.

While the corrosion products were expected to be aluminium oxides or chlorides, the finding of hydromagnesite and magnesium acetate suggested that the source of the problem was likely to be the storage conditions: both camera and the cellulose acetate films were stored together in an acid-containing cardboard box leading to

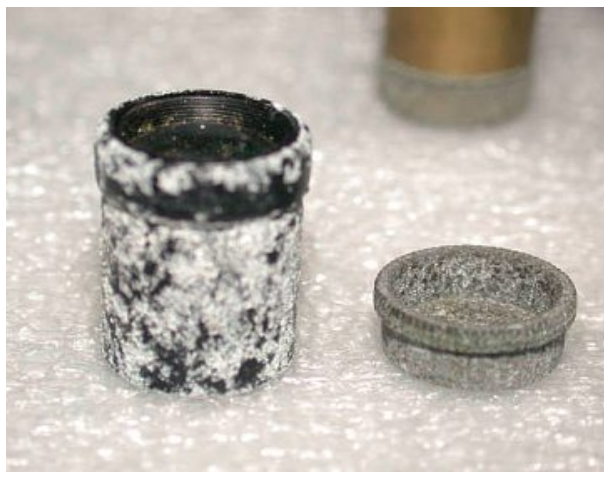

Fig. 6. Objective and reel cap 


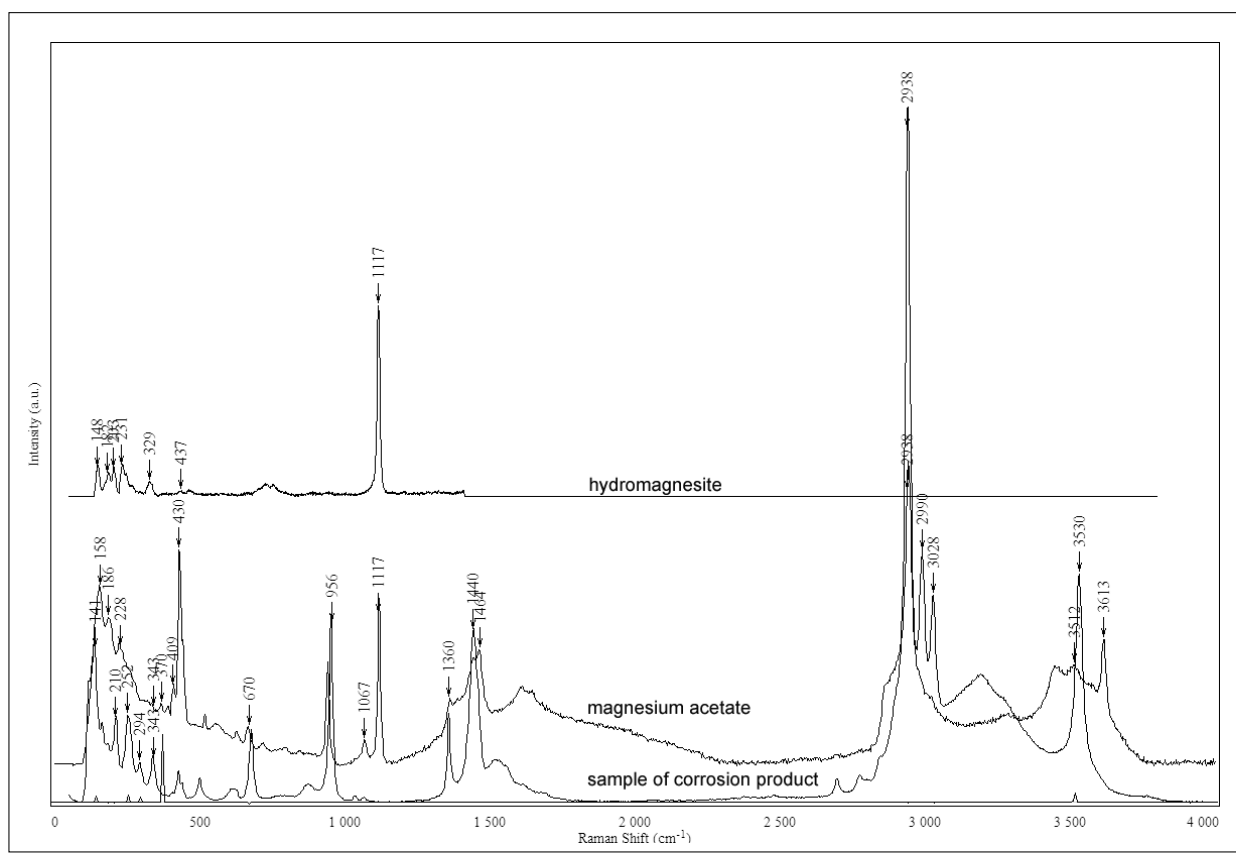

Fig. 7. Raman spectrum of the corrosion products in comparison with hydromagnesite and magnesium acetate

progressive corrosion. With this information at hand, the conservator first changed the storage conditions by using acid-free cardboard and storing the cellulose acetate films in a separate container. Furthermore, the information helped to adapt the conservation treatment to this particular type of corrosion. After removing the thickest corrosion layers mechanically, most of the remaining corrosion was removed by applying compresses with a mixture of ammonium citrate, EDTA and phosphoric acid. Subsequently, the last corrosion layers were stabilised with sodium benzoate and the surfaces were protected with mineral oil and wax. The objects can now be viewed at the Swiss Camera Museum in Vevey.

\section{Case Study 3: Raman Spectroscopy in Preventive Conservation}

An important mission of our laboratory is conservation research in matters of preventive conservation. During the last decade, preventive conservation has become one of the most important tasks in a modern museum's work. Currently, the 110-year-old headquarters of the Swiss National Museum are being reconstructed due to structural damage. Furthermore, a completely new permanent exhibition is planned. It will present objects from the Stone Age to the early modern period and will be re-opened to the public in August 2009.

With respect to object handling and exhibition conditions, the Collections Centre is closely involved in the planning and realisation processes. Each material used in the exhibition, such as walls for the differ- ent compartments, textiles and wood panels for showcases, paints and varnish, glues and different synthetic materials etc. are potential emitters of gaseous pollutants which may cause deterioration of artefacts. Thus, all these materials are carefully tested by our laboratory.

One of the tests is the $\mathrm{pH}$ measurement of small pieces of the chosen material which is agitated in water for $24 \mathrm{~h}$; another is an accelerated corrosion test known as the 'Oddy test' in conservation literature.[11] A small amount of the chosen material is put into a snap lid vial. A further, smaller vial containing pure water is then inserted. At the top of this vial, a small polished metal coupon is attached and the whole assembly is closed and sealed carefully. The metals used in this test are copper, silver and lead. The test vials are stored for 28 days at $60{ }^{\circ} \mathrm{C}$, simulating extreme conditions with high temperature and $100 \%$ relative humidity.

In the event of an emission of corrosive pollutants the metal coupons will show dif-
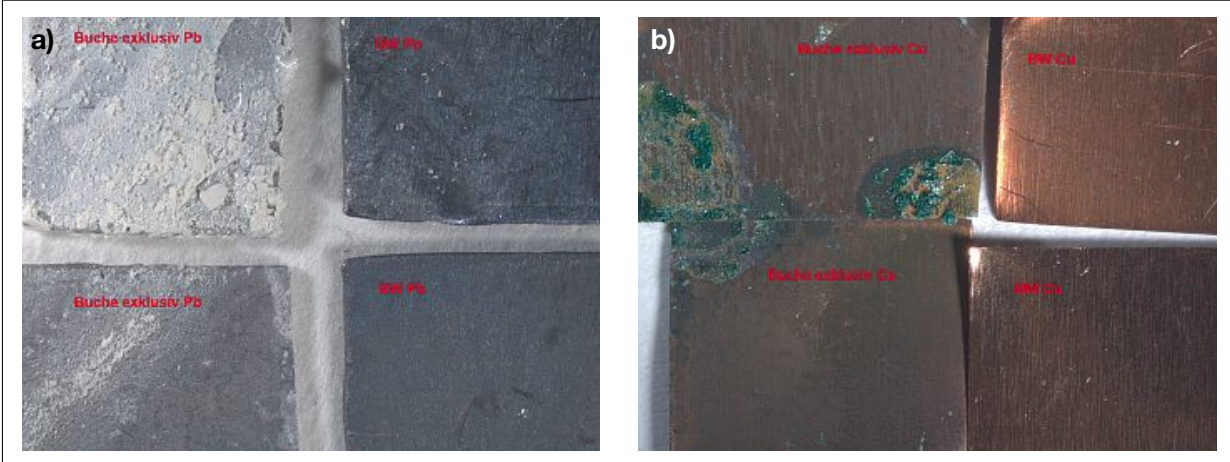

Fig. 8. Lead (a) and copper (b) coupons after the Oddy test ferent corrosion products on their surfaces. The absence or presence of corrosion and the grade of corrosion gives information about the usability of the tested material. Nowadays, a modified test is normally applied and the material's usability is classified into three main groups. These are: $\mathrm{P}$ for permanent use denoting that no corrosion is visible; $\mathrm{T}$ for temporary use; and $\mathrm{U}$ for unsuitable use. This classification is carried out by optical methods. ${ }^{[11]}$ The nature of the corrosion can deliver information on the emitted pollutant. This is the reason why the three mentioned metals are chosen: Copper is sensitive to sulphur compounds and reacts to form black copper sulphide. It also forms copper acetate through reaction with organic acids (acetic acid) in humid conditions. Furthermore, corrosion to copper chloride caused by chlorine compounds is possible. Silver is highly vulnerable to sulphur compounds producing brown to black corrosion products. Lead is also highly sensitive to organic acids like acetic or formic acid as well as to formaldehyde, reacting to form unstable intermediates like lead acetate which then transform to a stable white corrosion layer of lead carbonate. [12,13]

Our laboratory has tested more than 40 different materials so far for the new permanent exhibition of the Swiss National $\mathrm{Mu}$ seum. As expected, especially the different light wood products showed a clearly visible corrosion on the lead and copper coupons (two examples are shown in Fig. 8a and $b$ ). To identify the corrosion products these metal coupons were investigated by Raman spectroscopy. The Raman spectra were carried out directly on the white corrosion products of the lead coupons as well as on the green ones of the copper coupons. These measurements were performed using the $532 \mathrm{~nm}$ laser and the $100 \times$ objective (1 $\mu \mathrm{m}$ spot size). The green corrosion on the copper coupons could be identified as copper acetate, while the white corrosion on lead is a mixture of lead acetate and lead carbonate (Fig. 9). Both lead acetate and lead carbonate are white products, making it difficult to distinguish them optically. 


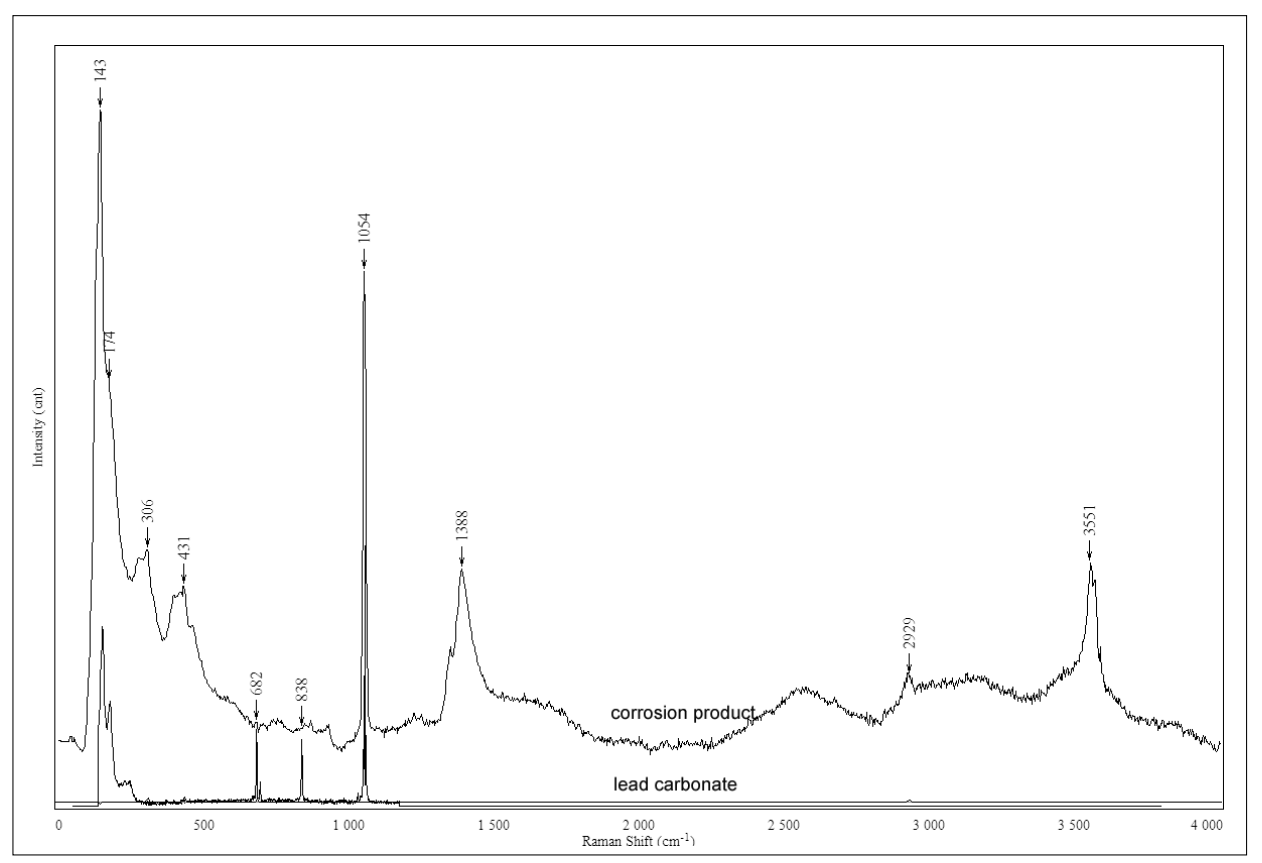

Fig. 9. Raman spectrum of the white corrosion layer on the lead coupons

Lead corrosion is caused by organic acids or even aldehydes (via oxidation) and known to develop a stable lead carbonate layer on the metal surface. By identifying lead acetate we could be sure that the corrosion was caused by acetic acid. The second proof for the pollution caused by acetic acid is the characterisation of the copper corrosion as copper acetate. Based on these analyses, the light wood products had to be classified as $\mathrm{U}$ - unsuitable for use with the permanent exhibition of the Swiss National Museum at least in direct contact or in the neighbourhood of precious exhibition objects.

\section{Conclusion}

This paper presented three practical applications of Raman spectroscopy at the laboratory for conservation research of the Swiss National Museums. The major advantage of micro-Raman spectroscopy as a complementary tool is its nondestructive applicability to a wide range of organic and inorganic materials. Material characterisation may help e.g. archaeologists to learn more about the materials used, how they were processed and even reconstruct trading routes based on provenance information. Planning of conservation strategies very often requires detailed knowledge about the corrosion products of the treated objects. The presented case documents the fundamental importance of such knowledge for further treatment of the objects by the conservator. To emphasise the wide applicability of this tool in conservation and restoration, material testing improves the careful selection of materials for use in conservation and ex- hibitions. Combined with non-destructive elemental analysis, Raman spectroscopy has thus become established as a very useful tool in research on conservation of cultural artefacts.

\section{Acknowledgements}

The authors thank the archaeologists and photographers of the 'Archäologischer Dienst des Kantons Bern' as well as the conservators of the Collection Centre of the Swiss National Museums for very interesting and interdisciplinary teamwork. We also thank the Swiss National Museum Zurich for its financial support.

Received: October 10, 2008

[1] M. Leuthard, B. Schüle, M. Wörle, 'Das Sammlungszentrum', Bundesamt für Bauten und Logistik, BBL Bern, 2007, 75.

[2] D. A. Long, J. Raman Spectrosc. 2008, 39, 316 .

[3] C. Coupry, Analusis 2000, 28, 39.

[4] C. Coupry, A. Lautie, M. Revault, J. Dufilho, J. Raman Spectrosc. 1994, 25, 89.

[5] P. Vandenabeele, J. Raman Spectrosc. 2004, 35, 607.

[6] M. Ramstein, C. Hartmann, 'Langenthal, Unterhard. Gräberfeld und Siedlungsreste der Hallstatt- und Latènezeit, der römischen Epoche und des Frühmittelalters', Rub Media, Bern, 2008.

[7] S. Greiff, 'Naturwissenschaftliche Untersuchungen zur Frage der Rohsteinquellen für frühmittelalterlichen Almandingranatschmuck Rheinfränkischer Provenienz', Jahrbuch des RGZM 1998.

[8] B. Kuhn, K. Hunger, A. Koch, A. Motschi, E. Reusser, M. Soares, 'Micro-Raman and X-Ray Fluorescence Spectroscopy for the Study of Merovingian Garnet Jewellery', Poster, 3rd International Conference on the Application of Raman Spectroscopy in Art and Archaeology, Paris, 2005.

[9] T. Calligaro, S. Collinart, J.-P. Poirot, C. Sudres, Nuclear Instruments and Methods in Physics Research B 2002, 189, 320.

[10] 'Des Pigeons Photographes', a report of the Musée Suisse de l'appareil photographique Vevey, 2007.

[11] L. R. Lee, D. Thickett, 'Selection of Materials for the Storage or Display of Museum Objects', British Museum, Occasional Paper 111, The British Museum Company Ltd, 46 Bloomsbury Street, London WC1B 3QQ, 1996.

[12] A.Schieweck, T. Salthammer, 'Schadstoffe in Museen, Bibliotheken und Archiven, Raumluft-Baustoffe-Exponate', Wolfram Schmidt Buchbinderei und Druckerei, Braunschweig, 2006.

[13] J. Tétreault, J. Sirois, E. Stamatopoulou, Studies in conservation 1998, 43, 17. 